\title{
PRINCIPAL COMPONENTS ANALYSIS FOR QUALITY EVALUATION OF COOLED BANANA 'NANICÃO’ IN DIFFERENT PACKING'
}

\author{
JULIANA SANCHES ${ }^{2}$, PAULO ADEMAR MARTINS LEAL ${ }^{3}$, JOSÉ HENRIQUE SARAVALI ${ }^{4}$, SILVIA ANTONIALI $^{5}$
}

\begin{abstract}
This work aims determinate the evaluation of the quality of 'Nanicão' banana, submitted to two conditions of storage temperature and three different kinds of package, using the technique of the Analysis of Principal Components (ACP), as a basis for an Analysis of Variance. The fruits used were 'Nanicão' bananas, at ripening degree 3, that is, more green than yellow. The packages tested were: “Torito" wood boxes, load capacity: 18 $\mathrm{kg}$; " $1 / 2$ box" wood boxes, load capacity: $13 \mathrm{~kg}$; and cardboard boxes, load capacity: $18 \mathrm{~kg}$. The temperatures assessed were: room temperature (control); and $\left(13 \pm 1^{\circ} \mathrm{C}\right)$, with humidity controlled to $90 \pm 2,5 \%$. Fruits were discarded when a sensory analysis determined they had become unfit for consumption. Peel coloration, percentages of imperfection, fresh mass, total acidity, $\mathrm{pH}$, total soluble solids and percentages of sucrose were assessed. A completely randomized design with a 2-factorial treatment structure (packing X temperature) was used. The obtained data were analyzed through a multivariate analysis known as Principal Components Analysis, using S-plus 4.2. The conclusion was that the best packages to preserve the fruit were the $1 / 2$ box ones, which proves that it is necessary to reduce the number of fruits per package to allow better ventilation and decreases mechanical injuries and ensure quality for more time.
\end{abstract}

Index terms: Musa cavendishii, quality, multivariate analysis.

\section{ANÁliSE DE COMPONENTES PRINCIPAIS PARA AVALIAÇÃO DA QUALIDADE DE BANANA 'NANICÃO' REFRIGERADA E EM DIFERENTES EMBALAGENS}

RESUMO - Este trabalho tem por objetivo a avaliação da qualidade de banana 'Nanicão', submetida a duas condições de temperatura de armazenamento e três tipos de embalagens, utilizando a técnica da Análise de Componentes Principais (ACP), como suporte à Análise de Variância. A fruta utilizada foi banana 'Nanicão', com coloração de grau "três", ou seja, mais verde que amarelo. As embalagens testadas foram: Madeira "torito", com capacidade para $18 \mathrm{~kg}$ de frutas; madeira chamada de $1 / 2$ caixa, com capacidade para $13 \mathrm{~kg}$ e papelão de capacidade para $18 \mathrm{~kg}$ de bananas. As temperaturas testadas foram: ambiente sem controle (testemunha) e $\left(13 \pm 1^{\circ} \mathrm{C}\right)$, com controle de umidade ajustada para $90 \pm 2,5 \%$. O descarte das frutas foi realizado quando as mesmas se tornaram impróprias para o consumo, baseado na análise sensorial. Foram avaliados a coloração da casca, porcentagem de imperfeições, massa fresca, acidez total titulável, $\mathrm{pH}$, sólidos solúveis totais e porcentagem de sacarose. O delineamento experimental foi o inteiramente casualizado, sendo a estrutura de tratamentos fatorial (embalagem X temperatura). Os dados obtidos foram analisados por análise multivariada, utilizando o método da Análise de Componentes Principais do "software" S-PLUS. Chegou-se à conclusão que a melhor embalagem para o acondicionamento das frutas é a $1 \frac{1}{2}$ caixa, provando que a redução no número de frutas por embalagem se faz necessária para obter maior área de ventilação e diminuição de danos mecânicos, preservando a qualidade por mais tempo.

Termos para indexação: Musa cavendishii, qualidade, análise multivariada.

\section{INTRODUCTION}

According to Chitarra \& Chitarra (1990), combining the use of the refrigeration chain and proper packaging should make it easier to conserve the quality of bananas until they reach the end consumer. The packaging processes do not improve the quality of the product, but help preserving it. Thus, only the best products should be packaged. Just as packaging is not a substitute for refrigeration, quality will be maintained when good packaging conditions are associated with good conditions of post-harvest treatments.

During the packaging process of bananas some special cares must be taken, such as: using suited packages; respecting the volume of fruits recommended for each kind of package; placing the clusters properly, according to each kind of package; avoiding damaging fruits against the package walls; and using plastic or cardboard protection materials to separate the clusters within the packages (Lichtemberg, 1999).

According to Bleinroth (1995), bananas may be kept at $12^{\circ} \mathrm{C}$ externally and $13^{\circ} \mathrm{C}$ within the pulp. Lower temperatures cause physiological damages to the peel, also called chilling injury, such as graying and browning.

A statistical multivariate analysis may be used to analyze the chemical variables and their variations throughout the banana ripening process. A multivariate analysis method called Analysis of Principal Components (ACP) reduces the dimension of a set of multivariate data, in an interpretative way. Through (deterministic) mathematical procedures, a set of variables, be it correlated or not, is transformed into a new set of uncorrelated variables, called principal components. The principal components are the linear combinations of a given set of variables, constructed as to "explain" as much as possible of the total variance of the original variables (Hoffmann, 1992). Thus, the data structure (originally individuals are represented in k-space), is usually simplified in terms of representation. Most of the information contained in the data may often be represented in $\mathrm{R}^{3}$, or even in a plane. The principal components technique condensates the variance of a set of data into a few axes, allowing to visualize most of the variability of the original data in two or three dimensions (components). The advantage of this technique is that the variables obtained may be interpreted independently (Moreira et al., 1994).

Within that context, this work aims at assessing the quality of 'Nanicão' bananas (Musa cavendishii) submitted to two conditions of storage temperature and three different kinds of package, using the technique of the Analysis of Principal Components (ACP), as a basis for an Analysis of Variance.

\section{MATERIALANDMETHODS}

The fruits used in this study were 'Nanicão' bananas, at ripening degree 3, that is, more green than yellow, harvested in Registro, region of the Vale do Ribeira, SP (Brazil).

\footnotetext{
${ }^{1}$ (Trabalho 005/2003). Recebido: 10/02/2003. Aceito para publicação: 16/06/2003. Parte da dissertação de mestrado em Engenharia Agrícola na FEAGRI/UNICAMP do primeiro autor;

${ }^{2}$ Eng $^{\mathrm{a}}$ Agra . Msc., FEAGRI/UNICAMP, Cx.P.6011, 13083-970, Campinas-SP. julianasanches@ yahoo.com

${ }^{3}$ Professor Doutor, FEAGRI-UNICAMP. pamleal@agr.unicamp.br

${ }^{4}$ Bolsista de Iniciação Científica CNPq, FEAGRI/UNICAMP, Campinas-SP. saravali@ hotmail.com

${ }^{5}$ Eng $^{\mathrm{a}} \mathrm{Agr}^{\mathrm{a}}$, Doutoranda em Tecnologia Pós-Colheita, FEAGRI/UNICAMP. antoniali@yahoo.com
} 
TABLE 1- Correlations, proportion of the variance and total proportion of the variance between the initial variables and the principal components.

\begin{tabular}{cccc}
\hline & Comp. 1 & Comp.2 & Comp. 3 \\
\hline Acidity 1 & -0.9529878 & 0.2508587 & -0.0857728 \\
Acidity 3 & -0.7992602 & 0.1302166 & -0.4239365 \\
Total soluble solids 1 & 0.9594710 & 0.0165021 & -0.0208485 \\
Total soluble solids 3 & 0.9238271 & 0.2965401 & -0.0877846 \\
pH 1 & 0.9169461 & -0.1783029 & 0.2378543 \\
pH 3 & 0.8605648 & 0.0715111 & 0.3850852 \\
\% sucrose 1 & 0.7869865 & 0.4755259 & -0.1597354 \\
\% sucrose 3 & 0.8766621 & 0.0126556 & -0.3502211 \\
\% weight loss 1 & 0.6792082 & -0.6323468 & -0.3193741 \\
Peel coloration 3 & 0.9571694 & -0.2313939 & -0.7304560 \\
Peel coloration 3 & 0.9774208 & 0.1147738 & -0.0729224 \\
Peel imperfections 1 & 0.9637658 & 0.1833236 & -0.0535435 \\
Peel imperfections 3 & 0.9797608 & 0.0726132 & -0.0568583 \\
\hline Proportion of Variance. & 0.9900764 & 0.0615665 & 0.0294884 \\
Total Proportion of Variance & 0.8208690 & 0.0671811 & 0.0477056 \\
\hline
\end{tabular}

Where: $1=$ storage day $1 ; 3=$ storage day 3

The packages tested were made of: Wood of the "torito" kind: internal dimensions: 495 × 375 × $270 \mathrm{~mm}$, load capacity: $18 \mathrm{~kg}$; Wood (the so-called $1 / 2$ box): internal dimensions: $470 \times 390$ x $190 \mathrm{~mm}$, load capacity: $13 \mathrm{~kg}$; and Cardboard: internal dimensions: 480 × 385 x 250 $\mathrm{mm}$, load capacity: $18 \mathrm{~kg}$.

Two temperatures were tested: room temperature with no further controls (control); and $13 \pm 1{ }^{\circ} \mathrm{C}$, with humidity controlled to $90 \pm 2.5 \%$.

The packages containing the fruits were stored in a cold room in the Laboratório de Controle Ambiental (Laboratory of Environmental Control) at FEAGRI/UNICAMP, Campinas - SP. The fruits were assessed at storage days 1,2, 3, 5 and 8, and were discarded when a sensory analysis found them unfit to consumption.

This sensory analysis assessed imperfections (injury detection based on the norms of classification and standardization issued by CEAGESP [São Paulo State Markets and Warehouse Company]) and the coloration of the fruits. Assessment was performed by $14 \mathrm{se}-$ lected, trained panelists using a $10 \mathrm{~cm}$ unstructured scale.

The physical-chemical analyses as to check the fruit quality throughout storage assessed: loss of mass, total titrable acidity, $\mathrm{pH}$, total soluble solids and percentages of sucrose.

A completely randomized design (CRD) with a 2-factorial treatment structure (packing $\mathrm{X}$ temperature) was used and repeated three times per package. Six bunches were assessed per package / repetition.

To analyze the obtained data a multivariate analysis method called the Analysis of Principal Components (ACP) was performed using S-plus 4.2 (1997). Then, an Analysis of Variance was performed on the first and/or second principal component.

\section{RESULTSAND DISCUSSION}

The physical-chemical and sensory analyses assessed, called variables, were transformed into a one variable.

Table 1 expresses the proportion of the variance, the total proportion of the variance and the correlations between the initial variables and the new variables, called principal components. As the first principal component accounts for $82.1 \%$ of the variability of the data, it may perfectly be used to represent the set of the variables measured for the packages and temperatures tested, since it incorporates over $80 \%$ of the variance. This table also shows that the coefficients of the first principal component are highly related to all the variables tested, more particularly to peel imperfections at storage day 3 , whose coefficient was that of major charge. It also shows that acidity at storage day 1 and storage day 3 was negative, which means that the fruits ripened between storage day 1 and storage day 3 .
Figure 1 elucidates the relationship between the first two principal components of storage day 1 and storage day 3 of the fruits. The ellipse highlights the fact that packages 1 to 9 , which correspond to room temperature storage, stand on the positive side of the axis of the first principal component, indicating faster ripening than storage at $13^{\circ} \mathrm{C}$ (numbers 10 to 18 ). Thus, the axis of component 1 (ripening) opposes room temperature and the $13^{\circ} \mathrm{C}$ temperature.

Component 1 also shows that the fruits were losing their quality at storage day 3 , mainly in the case of room temperature (Figure 1 ).

Table 2 presents the analysis of variance of component 1 .

That $\mathrm{F}_{\mathrm{TAB}, ; 0.05 ; 2 ; 12}=3,89>\mathrm{F}_{\mathrm{CALC} .}=3.87$ confirms the hypothesis that the packages present the same performance as for the period of storage, although very little $\left(\mathrm{P}_{\mathrm{VALUE}}=0.050\right)$, for the $5 \%$ level of prob-

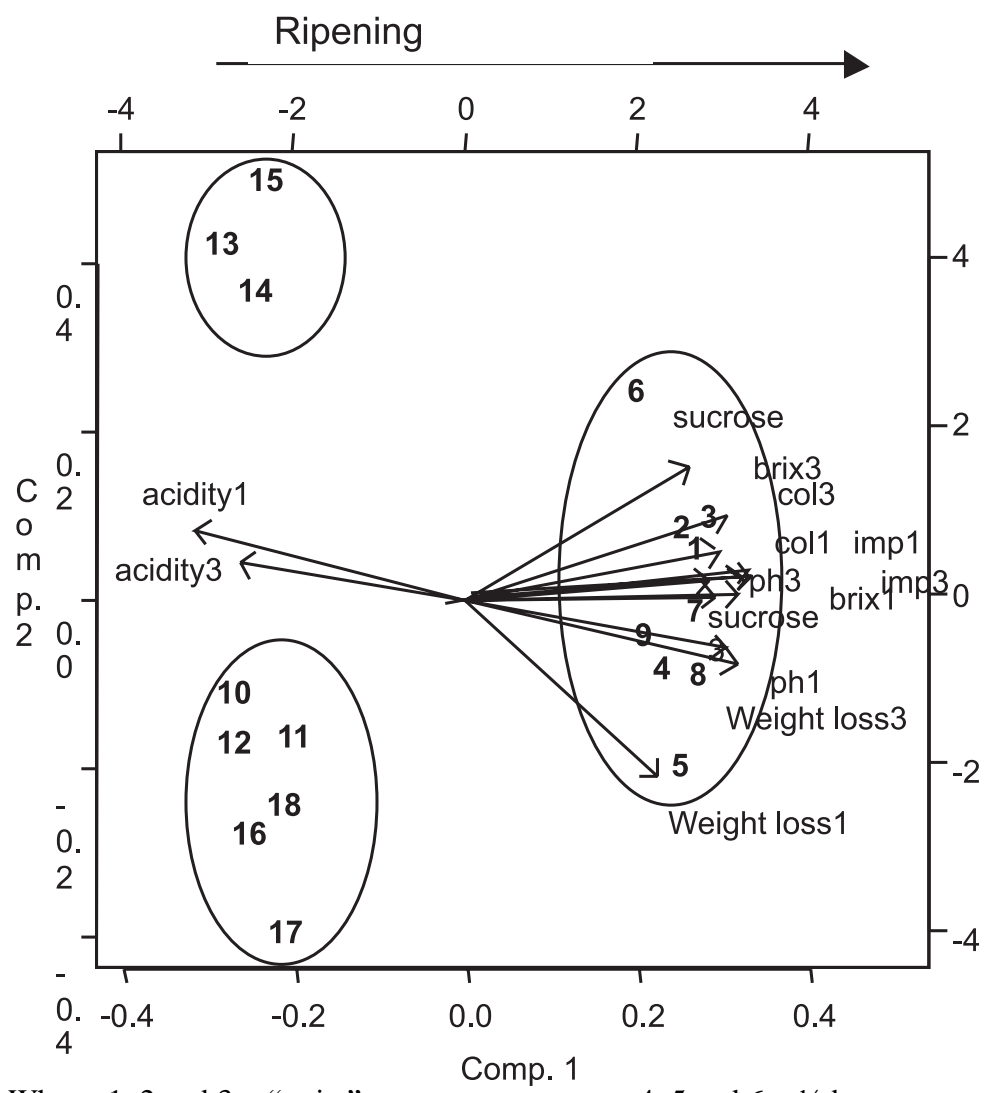

Where: 1,2 and $3=$ "torito" at room temperature; 4,5 and $6=1 / 2$ box at room temperature; 7,8 and $9=$ cardboard at room temperature; 10,11 and $12=$ "torito" at $13^{\circ} \mathrm{C} ; 13,14$ and $15=1 / 2$ box at $13^{\circ} \mathrm{C} ; 16,17$ and $18=$ cardboard at $13^{\circ} \mathrm{C}$.

FIGURE 1- Relationship between the two principal components as for the physical-chemical and sensory variables of the treatments between storage days 1 and 3 . 
ability, and allows to assert that the packages did not interfere with the variables of component 1 , until storage day 3 .

That $\mathrm{F}_{\mathrm{TAB} ; 0.01 ; 1 ; 12}=9.33<\mathrm{F}_{\mathrm{CALC} .}=2050.75$ invalidates the hypothesis that the temperatures present the same performance as for the variables of component 1 , at the $1 \%$ level of probability. This entails that temperature had an influence on the fruit quality in terms of storage time, and room temperature (control) presented an inferior fruit quality from storage day 3 .

As for interaction, $\mathrm{F}_{\mathrm{TAB} . ; 0.05 ; 2 ; 12}=3.89>\mathrm{F}_{\mathrm{CALC} .}=1.17$ confirms there are no interaction effects between the kind of package and the temperature of component 1 (Table 2), at the 5\% level of probability. Thus, temperature had no influence on the packages tested.

Table 3 expresses the proportion of the variance, the total proportion of the variance and the correlations between the initial variables and the new variables, called principal components, from storage day 1 to storage day 8 . At $13^{\circ} \mathrm{C}$, the first two principal components account for $56.7 \%$ of the variability of the data. Thus, these components can be used to represent the set of variables measured in the packages tested, since they incorporate over $56 \%$ of the variance. In addition, the coefficients of the first principal component are highly related to the total titrable acidity at storage days 1 and 5, to total soluble solids at storage day 3 , to $\mathrm{pH}$ at storage days 3 and 8 , to peel coloration at storage days 3,5 , and 8 and to peel imperfections at storage day 8 . Furthermore, the percentage of weight loss at storage

TABLE 2 - Table of the Analysis of Variance of component 1.

\begin{tabular}{lcccc}
\hline Source of Variation. & D. F. & $\begin{array}{c}\text { Sum of } \\
\text { Squares }\end{array}$ & $\begin{array}{c}\text { Mean } \\
\text { Square. }\end{array}$ & F \\
\hline Package & 2 & 0.77 & 0.39 & 3.87 \\
Temperature & 1 & 204.65 & 204.65 & 2050.75 \\
Package X Temperature & 2 & 0.23 & 0.12 & 1.17 \\
Remainder & 12 & 1.198 & 0.99 & - \\
\hline
\end{tabular}

days 1,3 and 5 and $\mathrm{pH}$ at storage day 1 are negative, which indicates that the fruits ripened until storage day 5 .

Component 1 shows that the fruit quality of the cooled packages maintained until storage day 3 , but already shows inferior quality at storage day 5 . At storage day 8 , the fruits presented a $\mathrm{pH}$ decrease and an increase in peel imperfections, which also influenced the fruit quality.

The second principal component shows a high positive correlation with the percentage of sucrose at storage days 3,5 and 8 , which confirms that the percentage of sucrose increased until storage day 8 and indicates ripening on the last day of storage.

Figure 2 elucidates the relationship between the first two principal components from storage day 1 to storage day 8 of the fruits. The ellipse highlights the facts that the packages numbered 1,2 and 3 ("torito") stand on the positive side of the axis of the first principal component. This means faster ripening and, consequently, a loss of quality as compared to the other packages.

Table 4 presents an analysis of the variance of component 1 , for the packages tested in the cooled environment.

That the value of $\mathrm{F}_{\mathrm{TAB}, 0.01 ; 2 ; 6}=10,92<\mathrm{F}_{\mathrm{CALC}}=34.51$ invalidates the hypothesis that the packages presented the same behavior when cooled, as for the variables of component 1 , at the $1 \%$ level of significance. Actually, this means that the packages presented different behaviors, as for the fruit quality, at a $13^{\circ} \mathrm{C}$ temperature (Table 4).

TABLE 4- Table of the Analysis of Variance of component 1, as for storage day 1 to storage day 8 of the fruits, at $13^{\circ} \mathrm{C}$.

\begin{tabular}{ccccc}
\hline Source of Variation. & D. F. & Sum of Squares & Mean Square. & F \\
\hline Packages & 2 & 94.0614 & 47.0307 & 34.51 \\
Remainder & 6 & 8.1769 & 1.3628 & - \\
\hline Total & 8 & 102.2383 & - & -
\end{tabular}

TABLE 3 - Correlations, proportion of the variance and total proportion of the variance between the initial variables and the principal components, between storage day 1 and storage day 8 , at $13^{\circ} \mathrm{C}$

\begin{tabular}{|c|c|c|c|}
\hline & Comp. 1 & Comp. 2 & Comp. 3 \\
\hline Acidity 1 & 0.8926739 & -0.2147247 & -0.2265076 \\
\hline Acidity 3 & 0.3601420 & -0.5472888 & 0.5073713 \\
\hline Acidity 5 & 0.6322265 & -0.1609002 & 0.1856689 \\
\hline Acidity 8 & -0.3483883 & -0.3388572 & 0.5590448 \\
\hline Total soluble solids 1 & -0.5015140 & -0.4512859 & -0.4044890 \\
\hline Total soluble solids 3 & 0.7002629 & -0.5384030 & -0.0516472 \\
\hline Total soluble solids 5 & -0.2280119 & 0.5742041 & -0.5014985 \\
\hline Total soluble solids 8 & -0.5019351 & 0.3879159 & -0.0712219 \\
\hline pH 1 & -0.8827111 & -0.2217665 & 0.3222203 \\
\hline pH 3 & 0.6330731 & 0.0403890 & -0.6230627 \\
\hline pH 5 & -0.1926843 & -0.3816025 & 0.7830227 \\
\hline pH 8 & 0.9538915 & -0.0086411 & -0.0041857 \\
\hline$\%$ sucrose 1 & 0.4863273 & -0.5457850 & -0.0214814 \\
\hline$\%$ sucrose 3 & 0.1369987 & 0.8700137 & 0.1099132 \\
\hline$\%$ sucrose 5 & 0.4624220 & 0.7493363 & 0.2601962 \\
\hline$\%$ sucrose 8 & -0.1580298 & 0.6047631 & 0.0573261 \\
\hline$\%$ weigh loss 1 & -0.8593801 & 0.0733209 & 0.4666942 \\
\hline$\%$ weigh loss 3 & -0.8853104 & 0.0700249 & 0.3612516 \\
\hline$\%$ weigh loss 5 & -0.7978605 & 0.0766812 & 0.2623181 \\
\hline$\%$ weigh loss 8 & -0.5297980 & 0.2664984 & 0.0836311 \\
\hline Peel coloration 1 & 0.5094476 & 0.2513831 & 0.4008478 \\
\hline Peel coloration 3 & 0.7336354 & -0.0440441 & 0.5721862 \\
\hline Peel coloration 5 & 0.8994709 & 0.0172528 & -0.0916299 \\
\hline Peel coloration 8 & 0.8420477 & -0.1521788 & 0.3826997 \\
\hline Peel imperfection 1 & 0.5606972 & 0.4199874 & 0.6051731 \\
\hline Peel imperfection 3 & 0.5523784 & 0.5375333 & 0.1774875 \\
\hline Peel imperfection 5 & 0.3493016 & 0.4594695 & 0.2932852 \\
\hline Peel imperfection 8 & 0.8650979 & 0.1257856 & 0.0795258 \\
\hline Proportion of Variance. & 0.4057103 & 0.1609522 & 0.1365862 \\
\hline Total Proportion of Variance & 0.4057103 & 0.5666625 & 0.7032487 \\
\hline
\end{tabular}

Where: $1=$ storage day $1 ; 3=$ storage day $3 ; 5=$ storage day $5 ; 8=$ storage day 8 . 


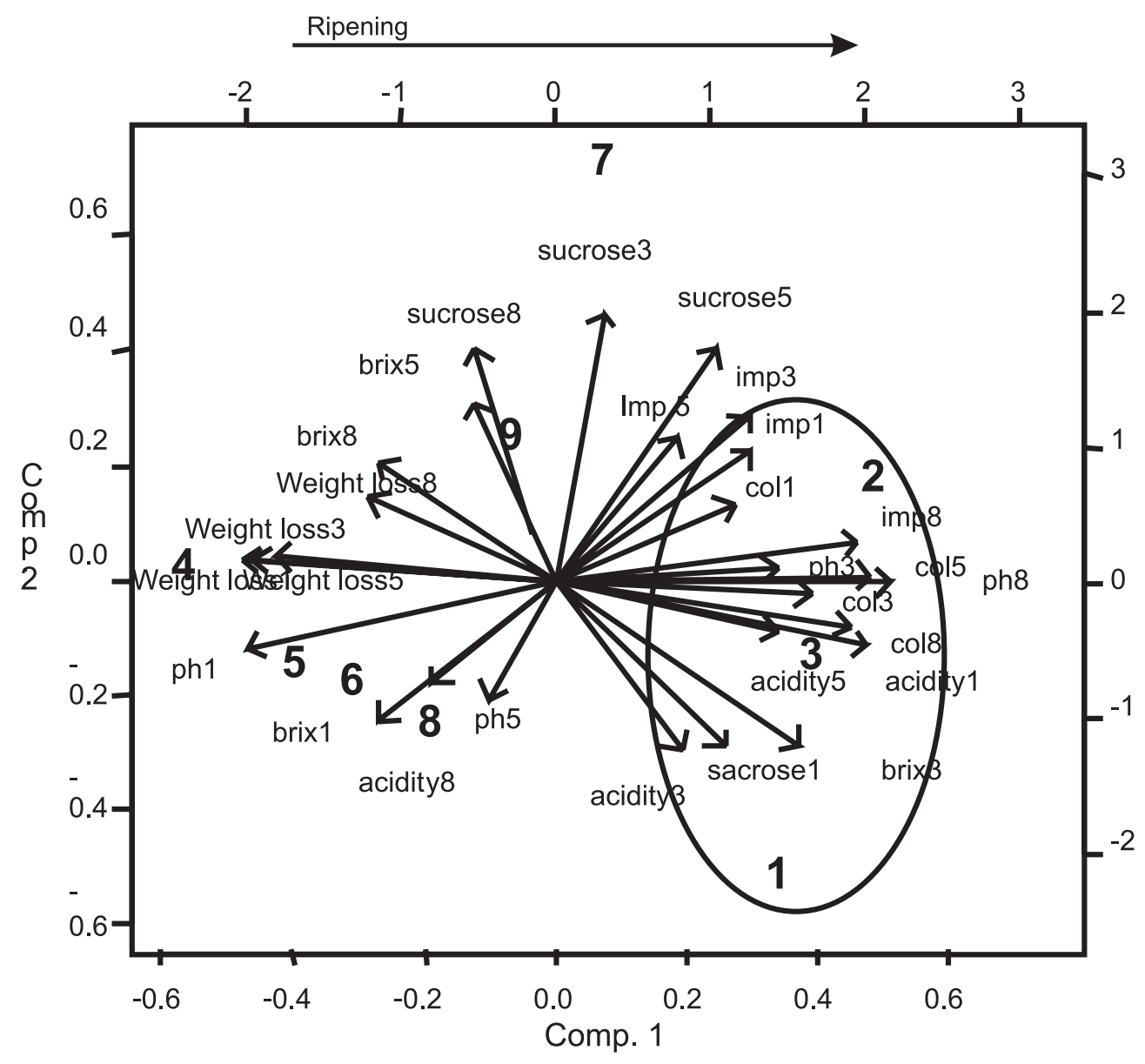

Where: 1,2 and $3=$ "torito"; 4,5 and $6=1 / 2$ box; 7,8 and $9=$ cardboard.

FIGURE 2 - Relationship between the two principal components as for the physical-chemical and sensory variables of the treatments from storage day 1 to storage day 8 , for the fruits stored at $13^{\circ} \mathrm{C}$.

The results of the statistical analyses of the $\mathrm{F}$ test described in the previous table show a significant difference at the $1 \%$ level of probability. The Tukey test shows that the packages tested between cool storage day 1 and cool storage day 8 had an effect. Therefore, the packages had an influence on the loss of the fruit quality (Table 5). The $1 / 2$ box package proved to be superior to the other packages, preserving the fruits better and the "torito" package was inferior to the other packages, as shown in Figure 2. This may be explained by the fact that the $1 / 2$ box package contained less fruits and had better ventilation than the other packages and, consequently, the fruit quality was superior to that of packages with major quantity of fruits.

That the value of $\mathrm{F}_{\mathrm{TAB}: 0.05 ; 2 ; 6}=10,92>\mathrm{F}_{\mathrm{CALC}}=1.22$ confirms the hypothesis that the variables (percentage of sucrose at storage days 3,5 and 8 ) of component 2 , were not influenced by the packages tested, at the $5 \%$ level of significance (Table 6). This means that, from storage day 1 to storage day 8 , at $13^{\circ} \mathrm{C}$, the fruits presented a uniform increase in their percentage of sucrose as for the three packages tested.

TABLE 5 - Test of Tukey for the means of component 1 for the packages tested from day 1 to day 8 of the fruit storage, at $13^{\circ} \mathrm{C}$.

\begin{tabular}{cc}
\hline \multicolumn{3}{c}{ Test of Tukey } \\
\hline DMS (Tukey)=2.9251 & $4.0580 \mathrm{~A}$ \\
\hline "Torito" & $-0.2052 \mathrm{~B}$ \\
Cardboard & $-3.8528 \mathrm{C}$ \\
$1 / 2$ Box &
\end{tabular}

TABLE 6 - Table of the Analysis of Variance of component 2, as for storage day 1 to storage day 8 of the fruits, at $13^{\circ} \mathrm{C}$.

\begin{tabular}{ccccc}
\hline Source of Variation. & D. F. & Sum of Squares & Mean Square. & F \\
\hline Packages & 2 & 11.7465 & 5.8732 & 1.22 \\
Remainder & 6 & 28.8127 & 4.8021 & - \\
\hline Total & 8 & 40.5591 & - & - \\
\hline
\end{tabular}

\section{CONCLUSIONS}

Grouping the results of the physical-chemical and sensory assessments of the fruits into a one variable, through the statistical method of the principal components, led to the conclusion that the best package for the fruits is the $1 / 2$ box one. This proves that reducing the number of fruits per package is necessary to obtain better ventilation, decrease the mechanical damages, and preserve quality for more time.

\section{ACKNOWLEDGMENTS}

To FEAGRI - UNICAMP, CNPq, CAPES and FAPESP(01/002752R) for their financial support.

\section{REFERENCES}

BLEINROTH, E. W. Banana: cultura, matéria-prima, processamento e aspectos econômicos. 2. ed. rev. e ampl. Campinas: Instituto de Tecnologia de Alimentos-ITAL, 1995.302p.

CHITARRA, M. I. F.; CHITARRA, A. B. Pós-Colheita de frutas e hortaliças: fisiologia e manuseio. Lavras: ESAL/FAEPE, 1990. 293p.

HOFFMAN, R. Componentes principais. Piracicaba: ESALQ, 1992. 25 p. (Série didática, 76).

LICHTEMBERG, L. A. Colheita e pós-colheita da banana. Informe Agropecuário, Belo Horizonte, v.20, n. 196, p. 73-90, jan./fev.1999.

MOREIRA, J. A. N.; SANTOS, J. W.; OLIVEIRA, S. R. M. Abordagens e metodologias para a avaliação de germoplasma. Campina Grande: EMBRAPA, 1994.

S-PLUS 4. Guide to Statistics. Data Analysis Products Division, MathSoft, Seattle, Washington, 1997. 877p. 